\title{
DNA-mediated Genetic Changes in Neurospora crassa
}

\author{
By N. C. MISHRA \\ Department of Biology, University of South Carolina, Columbia, \\ South Carolina 29208, U.S.A.
}

(Received 19 October 1978)

Evidence for genetic transformation in Neurospora crassa is based on the observations that allo-DNA has a specific effect in producing transformants which is abolished by DNAase treatment and that iso-DNA is not effective in transformation. Here, unambiguous evidence for genetic transformation is provided by transfer of a temperature-sensitive inositol requirement from a donor to a recipient strain. Data provided also suggest the role of growth conditions and the involvement of a nuclease gene in the DNA uptake and transformation of $N$. crassa.

\section{INTRODUCTION}

Transformation by nucleic acid molecules or isolated chromosomes provides unusual means for the transfer of genetic information in both prokaryotes and eukaryotes (Avery et al., 1944; Cosloy \& Oishi, 1973; Hotchkiss, 1976; Ottolenghi-Nightingale, 1974; Fox et al., 1970; McBride \& Ozer, 1973; Mishra et al., 1973; Mishra \& Tatum, 1973; Mishra, $1976 a, b$; Mishra, 1977; Ruddle \& Fournier, 1977). We have recently described the characteristics of such a genetic system in Neurospora crassa (Mishra et al., 1973; Mishra \& Tatum, 1973; Mishra, 1976 $a, b$; Mishra, 1977). Our original result [the transformation of an inositol-requiring (inl) strain to inositol independence $\left(\right.$ inl $\left.^{+}\right)$] has recently been confirmed (Mishra, 1977; Schablik et al., 1977). In these studies, the evidence for genetic transformation was: (i) that allo-DNA had a specific transforming effect which was abolished by treatment with DNAase and (ii) that iso-DNA (recipient DNA preparation) did not transform. Unequivocal proof of transformation, provided by transfer of a temperature-sensitive $(t s)$ character to a recipient strain, is presented in this paper. Previously, such experiments could not be performed due to the lack of temperature-sensitive mutants, but we have recently isolated inl ts mutants of $N$. crassa, which require inositol for growth only at $37^{\circ} \mathrm{C}$ and not at $25 \mathrm{C}^{\circ}$ (unpublished results); DNA from this inl $t s$ strain has been used in transformation. Our results show that an inl mutant of $N$. crassa, which requires inositol for growth at any temperature, can acquire temperature sensitivity for this requirement following treatment with DNA from a temperature-sensitive strain. There is evidence also that a young $N$. crassa culture is 'physiologically competent' for DNA uptake and transformation. A nuclease gene may be involved in transformation in $N$. crassa, since a nucleaseless (nuc-1) mutant when used as recipient showed both reduced DNA uptake and reduced frequency of transformation. Study of this transformation system could lead to an understanding of the molecular basis of transformation in eukaryotes.

\section{METHODS}

The multiply marked strain $2506\left(A, r g\right.$, arg, pan, nuc- $\left.1^{+}\right)$of Neurospora crassa carrying an inl allele (89601) was used as the recipient. A newly isolated temperature-sensitive strain (RL3-8A-2), which required inositol for growth at $37^{\circ} \mathrm{C}$ but not at $25^{\circ} \mathrm{C}$, was used as the donor in transformation. The recipient strain 
(2506) required inositol, arginine and pantothenic acid for growth at 25 and $37{ }^{\circ} \mathrm{C}$. The inositol loci in strains 2506 (inl) and RL3-8A-2 (inl ts) are allelic (unpublished results). These strains swere grown on appropriately supplemented medium (Vogel, 1964). DNA prepared from the temperature-sensitive strain (inl $t s$ ) (Mishra et al., 1973) was designated allo-DNA; DNA prepared from the recipient strain (2506) was designated iso-DNA. Young cultures $(30 \mathrm{~h})$ of the recipient strain were treated with allo-DNA $\left(50 \mu \mathrm{g} \mathrm{ml}^{-1}\right)$ and $\mathrm{CaCl}_{2}$ $(80 \mathrm{~mm})$. Recipient cultures without any DNA or treated with iso-DNA $\left(50 \mu \mathrm{g} \mathrm{ml}^{-1}\right)$ served as controls. Presumptive transformants from the treated culture were selected by plating on medium without inositol and incubating at $25^{\circ} \mathrm{C}$. Viable counts were performed by plating on medium containing inositol (Mishra et al., 1973). Transformant colonies growing on medium without inositol were isolated and their temperature sensitivity was determined. Those unable to grow on medium without inositol but able to grow with it at $37^{\circ} \mathrm{C}$ were designated temperature-sensitive $(t s)$ for inositol requirement. Only transformation of the inositol locus of the recipient strain was studied.

In other experiments, strains 2506 and $2506 \mathrm{M}$ were used as recipients; these were isogenic except that $2506 \mathrm{M}$ carried the mutant $(n u c-1)$ allele of the nuclease gene $\left(n u c-1^{+}\right)$(Ishikawa et al., 1969). The two strains were separately treated with donor DNA from the wild-type (inl ${ }^{+}$) strain RL3-8A in the presence of CaCl $(80 \mathrm{mM}) . \mathrm{Inl}^{+}$transformants were then selected on medium without inositol (Mishra et al., 1973). In the DNA uptake experiment, young $(30 \mathrm{~h})$ cultures of the recipients were incubated with ${ }^{32}$ P-labelled DNA $\left(50 \mu \mathrm{g} \mathrm{ml}^{-1}\right.$; sp.act. $6 \cdot 7 \times 10^{3}$ c.p.m. $\left.\mu \mathrm{g}^{-1}\right)$ for $1 \mathrm{~h}$ and then the DNAase-resistant radioactivity was measured in a Beckman LS230 scintillation counting system.

\section{RESULTS AND DISCUSSION}

\section{Transfer of a temperature-sensitive character}

DNA from a temperature-sensitive donor was used in transformation to examine whether the donor-specific genetic information could be transferred to a recipient. The results from three separate experiments are presented in Table 1. The frequency of transformation was $2 \cdot 3 \times 10^{-6}$. A significant number of the transformants (74 out of 95 examined) were unable to grow at $37^{\circ} \mathrm{C}$ in the absence of inositol. Since these transformants could grow at $37{ }^{\circ} \mathrm{C}$ when inositol was added to the medium, their temperature-sensitive character was specific with respect to the inositol requirement. Thus, they had acquired the $t s$ character of the donor DNA. The results also show that the $t s$ character of the transformants was a specific effect of the donor DNA since colonies obtained without any DNA or following treatment of the recipient with its own DNA (iso-DNA) were not temperature-sensitive. Some of the transformants which were not temperature-sensitive with respect to inositol requirement for growth could have originated from reversion of the inl locus (89601) of the recipient strain (2506). Others could have resulted from recombination between donor and recipient DNA molecules (Whitehouse, 1965; Yoshikawa, 1966; Mishra, 1977). The above results provide conclusive evidence for transformation at the inositol locus of $N$. crassa. To our knowledge, no such transfer of temperature-sensitive character mediated by allo-DNA in eukaryotes has been reported previously

\section{Table 1. Transformation of the inl recipient}

Recipient (inl) was treated with allo-DNA (inl ts) or iso-DNA (inl) as described in Methods; colonies growing on medium without inositol at $25^{\circ} \mathrm{C}$ were designated as transformants. Data from three or more experiments are presented.

$\begin{array}{lccc}\text { Treatment } & \begin{array}{c}\text { No. of } \\ \text { trans- } \\ \text { formants } \\ \text { examined }\end{array} & \overbrace{\text { inl ts }}^{\begin{array}{c}\text { No. of transformants } \\ \text { of each genotype }\end{array}} \\ \text { Allo-DNA } & 95 & 74 & \text { inl }^{+} \\ \text {Iso-DNA } & 7 & 0 & 21 \\ \text { No DNA } & 9 & 0 & 7\end{array}$

* inl $t s$ requires inositol for growth at $37^{\circ} \mathrm{C}$ but not at $25^{\circ} \mathrm{C}$; inl ${ }^{+}$does not require inositol for growth at any temperature. 
Table 2. [ $\left.{ }^{32} P\right] D N A$ uptake by mycelium

A young culture $(30 \mathrm{~h})$ of strain $2506\left(n u c-l^{+}\right)$was incubated for $1 \mathrm{~h}$ with [ $\left.{ }^{32} \mathrm{P}\right] \mathrm{DNA}$ (sp.act. $6.7 \times 10^{3}$ c.p.m. $\left.\mu \mathrm{g}^{-1}\right)$ in the growth medium.

$\begin{array}{cc}\text { DNA } & {\left[{ }^{32} \text { P]DNA uptake }\right.} \\ \left(\mu \mathrm{g} \mathrm{ml}^{-1}\right) & \left.\text { [c.p.m. (mg dry wt mycelium })^{-1}\right] \\ 16 & 13100 \\ 25 & 26300 \\ 50 & 39600 \\ 100 & 43200\end{array}$

\section{Effect of growth conditions on DNA uptake and transformation}

Since genetic transformation is related to the amount of DNA taken up, we investigated the growth conditions that influence DNA uptake by $N$. crassa mycelium. DNA uptake by a young culture $(30 \mathrm{~h})$ was linearly dependent on the amount of DNA added up to $50 \mu \mathrm{g} \mathrm{ml}^{-1}$ in the growth medium (Table 2), and on time up to $1 \mathrm{~h}$ incubation. The young culture, under optimal conditions, took up a maximum of $6 \mu \mathrm{g}$ DNA (mg dry wt mycelium) ${ }^{-1}$ which is equivalent to the DNA content of $1 \mathrm{mg}$ mycelium (Minagawa et al., 1959). DNA uptake by an old culture ( 40 to $60 \mathrm{~h}$ ) was much lower and was not proportional to the amount of DNA added (data not shown). In the presence of $\mathrm{CaCl}_{2}(80 \mathrm{mM})$, DNA uptake by the young mycelium was doubled. Addition of cyclic AMP or polyethylene glycol had no effect. However, in the presence of ATP $(2 \mathrm{mM})$, the amount of DNA uptake by young mycelium increased by $64 \%$, which may reflect the energy dependence of the process (Lacks, 1976).

The competence of young cultures suggested that they could be more efficiently transformed by allo-DNA. In three parallel experiments, young cultures $\left(10 \times 10^{6}\right.$ cells $)$ treated with allo-DNA yielded inl ${ }^{+}$transformants at a frequency of $1.8 \times 10^{-6}$, which was raised to $2 \cdot 3 \times 10^{-6}$ to $2 \cdot 7 \times 10^{-6}$ by the addition of $\mathrm{CaCl}_{2}$. Such a stimulatory effect of $\mathrm{CaCl}_{2}$ in bacterial transformation is well known but its role in transformation is unknown (Oishi \& Irbe, 1976). The frequency of transformation by allo-DNA was consistent in parallel experiments using young cultures as recipients. Neither young cultures without any DNA $\left(24 \times 10^{6}\right.$ cells analysed $)$ nor those with allo-DNA previously treated with DNAase $\left(5 \times 10^{6}\right.$ cells analysed) yielded $i n l^{+}$colonies. The frequency of transformation by allo-DNA varied in experiments involving old cultures $(40$ to $60 \mathrm{~h})$ of the recipient. These observations suggest that young $N$. crassa cultures possess a 'physiological preparedness or competence' for DNA uptake and transformation. Thus, the negative effect of allo-DNA reported previously (Mishra et al., 1973) can perhaps be ascribed to differences in the physiological conditions of the recipient cultures used which were of various ages.

\section{Role of nucleases in genetic transformation}

At least three groups of enzymes (nucleases, DNA-polymerases and ligases) involved in recombination are also known to be involved in the uptake and integration of donor DNA molecules during transformation in bacteria (Lacks et al., 1974; Lacks, 1976). We therefore compared the efficiency of a nuclease-less (nuc-1) mutant (2560M) with that of the wild-type $\left(n u c-1^{+}\right)$strain (2506) in DNA uptake and transformation. These multiply marked strains are isogenic except for the nuc-1 locus; nuc-1 mutants are deficient in certain nucleases (Ishikawa et al., 1969). The two strains were compared for their ability to take up [ ${ }^{32}$ P]DNA and for the transformation of the inl locus.

The amount of DNA taken up by the nuclease-less (nuc-1) strain (Table 3) was only about $40 \%$ of that taken up by the $n u c-1^{+}$strain. The $n u c-1$ recipients showed a 90 -fold reduction in the frequency of transformation compared with the wild-type recipient $\left(n u c-1^{+}\right)$. In genetic crosses between $n u c-1^{+}(\mathrm{inl})$ and $n u c-1$ (inl) strains, the $n u c-l(\mathrm{inl})$ progeny always 
Table 3. Effect of a nuclease-less mutation (nuc-1) on DNA uptake and the frequency of transformation

Uptake of [ ${ }^{32} \mathrm{P}$ ]DNA $\left(50 \mu \mathrm{g} \mathrm{ml}{ }^{-1}\right.$; sp.act. $6.7 \times 10^{3}$ c.p.m. $\left.\mu \mathrm{g}^{-1}\right)$ by young cultures $(30 \mathrm{~h})$ was measured after $1 \mathrm{~h}$ incubation. Data are based on three or more experiments.

$\begin{array}{ccc}\text { Strain } & \begin{array}{c}\text { [32P]DNA uptake } \\ {[\text { c.p.m. (mg dry wt }} \\ \text { mycelium) }\end{array} & \begin{array}{c}\text { Frequency of } \\ \text { in } l^{+} \text {transformants }\end{array} \\ 2506\left(n u c-1^{+}\right) & 39600 & 2 \cdot 7 \times 10^{-6} \\ 2506 \mathrm{M}(\text { nuc- }-1) & 15840 & 0 \cdot 03 \times 10^{-6}\end{array}$

showed a reduced frequency of transformation at the inl locus and a reduced DNA uptake in addition to nuclease deficiencies. These findings are similar to the effects of nuclease-less mutation on the frequency of bacterial transformation and suggest that nucleases may play a role in the uptake and integration of the donor DNA into recipient genomes during transformation in $N$. crassa as in bacteria (Lacks et al., 1969; Lacks, 1976). Schablik et al. (1977) reached the same conclusion by showing that DNA uptake by a young $N$. crassa culture was significantly reduced when the culture was repeatedly washed to remove extracellular nucleases. We have recently developed a large number of nuclease-less mutants of $N$. crassa (Forsthoefel \& Mishra, 1977) and with the use of these as recipients it may be possible to determine the role of nucleases in transformation. In addition, conditions which may lead to the evaluation of the DNA polymerases during transformation in $N$. crassa have been described (El-Assouli \& Mishra, 1978). Continuation of these studies should provide some understanding of the molecular basis of transformation (including recombination of DNA molecules) in higher organisms.

The author wishes to express his grateful appreciation to Drs S. F. H. Threlkeld and M. C. Niu for a critical review of the manuscript and thanks to Ms Polly Clary for her technical help. This work was supported in part by a grant from the National Institutes of Health (GM21520-04) and from the National Science Foundation (G13433061).

\section{REFERENCES}

Avery, O. T., McLeod, C. M. \& McCarthy, M. (1944). Studies on the chemical nature of substance inducing transformation in pneumococcal types. Journal of Experimental Medicine 79, 137-158.

CosLoY, S. D. \& OISHI, M. (1973). Genetic transformation in E. coli K12. Proceedings of the National Academy of Sciences of the United States of America 70, 84-87.

El-Assouli, S. \& Mishra, N.C. (1978). A Neurospora DNA polymerase. Naturwissenschaften 65, 63-64.

Forsthoefel, A. \& Mishra, N. C. (1977). Biochemical genetics of Neurospora crassa nucleases. Genetics (abstr.) S20.

Fox, A. S., DugGleby, F. W., Gelbart, W. M. \& Yoon, S. B. (1970). DNA induced transformation in Drosophila: evidence for transformation without integration. Proceedings of the National Academy of Sciences of the United States of America 67, 1834-1838.

Hotchkiss, R. D. (1976). Concluding remarks. In Modern Trends in Bacterial Transformation and Transfection, pp. 321-328. Edited by A. Portales, M. Lopez \& M. Espinosa. Amsterdam: North Holland.
Ishikawa, T., Toh-E, A., UNo, I. \& Hsaunuma, K. (1969). Isolation and characterization of nuclease mutants in Neurospora crassa. Genetics 63, 75-92.

LACKS, S. (1976). Binding and entry of DNA in pneumococcal transformation. In Modern Trends in Bacterial Transformation and Transfection, pp. 35-55. Edited by A. Portales, M. Lopez \& M. Espinosa. Amsterdam: North Holland.

Lacks, S., Greenberger, B. \& Neuberger, M. (1974). Role of a deoxyribonuclease in the genetic transformation of Diplococcus pneumoniae. Proceedings of the National Academy of Sciences of the United States of America 71, 2305-2309.

McBride, O. W. \& Ozer, H. L. (1973). Transfer of genetic information by purified metaphase chromosomes. Proceedings of the National Academy of Sciences of the United States of America 70, 1258-1262.

Minagawa, T., Wagner, B. \& Strauss, B. (1959). The nucleic acid content of Neurospora crassa. Archives of Biochemistry and Biophysics 80, 442-445.

Mishra, N. C. (1976a). Episome-like behaviour of donor DNA in transformed strains of Neurospora crassa. Nature, London 264, 251-253. 
Mishra, N. C. (1976b). DNA induced genetic changes in Neurospora crassa. In Modern Trends in Bacterial Transformation and Transfection, pp. 179-183. Edited by A. Portales, M. Lopez \& M. Espinosa. Amsterdam: North Holland.

MishrA, N. C. (1977). Characterization of the new osmotic mutants which originated during genetic transformation in Neurospora crassa. Genetical Research 29, 9-19.

Mishra, N. C. \& Tatum, E. L. (1973). NonMendelian inheritance of DNA induced inositol independence in Neurospora. Proceedings of the National Academy of Sciences of the United States of America 70, 3875-3879.

Mishra, N. C., Szabo, G. \& Tatum, E. L. (1973). The role of nucleic acid-induced genetic changes in Neurospora. In Nucleic Acids in Reproduction and Development, pp. 261-273. Edited by M. C. Niu \& S. J. Segal. Amsterdam: North Holland.

OISHI, M. \& IRBE, R. M. (1976). Circular chromosome and genetic transformation in $E$. coli. In Modern Trends in Bacterial Transformation and Transfection, pp. 121-134. Edited by A. Portales,
R. Lopez \& M. Espinosa. Amsterdam: North Holland.

Ottolenghi-Nightingale, E. (1974). DNA mediated transformation in mammalian cells. In Cell Communication, pp. 233-254. Edited by R.P. Cox. New York: Wiley.

Ruddle, R. H. \& Fournier, R. E. K. (1977). Somatic cell genetic analysis of gene transfer in mammalian cells. Brookhaven Symposia in Biology 29, 96-104.

Schablik, M., Szabolcs, M., Kiss, A., Aradi, J., Zsindeley, A. \& Szabo, G. (1977). Conditions of transformation by DNA of Neurospora crassa. Acta biologica Academiae scientiarum hungaricae 28, 273-279.

VoGEL, H. J. (1964). Evolution of lysin pathways I. Naturalist 98, 435-469.

WhITEHOUSE, H. L. K. (1965). In Towards an Understanding of the Mechanism of Heredity, 3rd edn, pp. 327-371. New York: St. Martin.

Yoshikawa, H. (1966). Mutations resulting from the transformation of Bacillus subtilis. Genetics 54, 1201-1214. 